\title{
A NOTE ON NON-RANDOM MATING \\ IN THE MOTH PANAXIA DOMINULA (L)
}

\author{
P. M. SHEPPARD \\ Genetics Laboratory, Department of Zoology, \\ University of Oxford
}

Received 19.xi. $5^{\text {I }}$

IN animals, examples of genes having marked morphological and physiological effects are well-known, but the control of behaviour by specific genes has been very little studied. Consequently, few genes are known which regulate the mating behaviour particularly with regard to the "choice" of mates. Moreover, most reports of nonrandom mating between individuals differing by a single major gene, suggest that like genotypes usually tend to mate together. Therefore it seems worthwhile recording the following observations on the effects of a single gene (not excluding other genes very closely linked with it) on mating behaviour.

In the moth, Panaxia dominula (L.), a gene showing no dominance is found at an appreciable frequency in one colony in Berkshire (Fisher and Ford, I947). The heterozygote is recognisable as var. medionigra and the rarer homozygote as var. bimacula. It has been suggested (Kettlewell, 1942) that mating between the three genotypes is not random. Because this observation was not based on strictly numerical data an experiment was designed to test the hypothesis (Sheppard, I95I). Although a tendency for unlike genotypes to pair was observed, the data were not extensive enough for useful conclusions to be based on them. Consequently, the work was repeated and extended in $195 \mathrm{I}$. The results of this new study together with the data previously reported (Sheppard, 195I) are given in table $\mathrm{I}$.

There is a very strong tendency $(\mathrm{P}<0 \cdot 00 \mathrm{I})$ for unlike genotypes to pair, and the result is not due to a different sex drive in the males of the three varieties. This can be verified, for medionigra and bimacula, from lines 7 and 8 in the table in which the only differences between the cages concern the females. A change from a bimacula to a medionigra female resulted in the bimacula males mating more often (table I, column 8), whereas before the medionigra males paired more frequently. Preliminary observations on the mating behaviour suggest that the disassortative pairing is controlled by the female. On several occasions she has been observed to reject actively a male of her own genotype, and has then at once accepted a male of a different form. The observations suggest that the courtship between like genotypes is longer than between unlike forms as the male will usually succeed in pairing with the female in the end, providing that a moth of another genotype is not present. The shorter the courtship the less chance there is of 
the other male in the cage interrupting it and mating with the female first. If there is only one male, then with a long courtship, it is more likely to be attracted by another female before copulation takes place than if the courtship is short.

TABLE I

\begin{tabular}{|c|c|c|c|c|}
\hline \multirow{2}{*}{\multicolumn{2}{|c|}{$\begin{array}{l}\text { Genotypes of } \\
\text { the three moths } \\
\text { in the cage }\end{array}$}} & \multicolumn{2}{|c|}{ Result of first mating } & \multirow[b]{2}{*}{ Totals } \\
\hline & & $\begin{array}{l}\text { Like geno- } \\
\text { typer pairing }\end{array}$ & $\begin{array}{l}\text { Unlike geno- } \\
\text { types pairing }\end{array}$ & \\
\hline I & $\begin{array}{l}\text { dominula ô } \\
\text { dominula o } \\
\text { medionigra } 9\end{array}$ & 8 & 20 & 28 \\
\hline 2 & $\begin{array}{l}\text { medionigra } a \\
\text { dominula o } \\
\text { medionigra }+9\end{array}$ & 12 & 14 & 26 \\
\hline 3 & 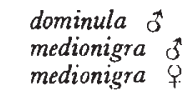 & I3 & 14 & 27 \\
\hline 4 & $\begin{array}{l}\text { dominula } \vec{\sigma} \\
\text { medionigra } \vec{\sigma} \\
\text { dominula } t\end{array}$ & II & 22 & 33 \\
\hline 5 & $\begin{array}{l}\text { medionigra } 0 \\
\text { medionigra } q \\
\text { bimacula } q\end{array}$ & 2 & 0 & 2 \\
\hline 6 & $\begin{array}{l}\text { bimacula } \sigma^{*} \\
\text { medionigra } Q \\
\text { bimacula } q\end{array}$ & $o$ & I & I \\
\hline 7 & $\begin{array}{l}\text { medionigra } \sigma^{*} \\
\text { bimacula o } \\
\text { bimacula }+\end{array}$ & 3 & 15 & 18 \\
\hline 8 & $\begin{array}{l}\text { medionigra }{ }^{\pi} \\
\text { bimacula }{ }^{*} \\
\text { medionigra }\end{array}$ & 2 & ro & I 2 \\
\hline 9 & $\begin{array}{ll}\text { dominula } & 0 \\
\text { dominula } & + \\
\text { bimacula } & +\end{array}$ & 2 & I & 3 \\
\hline & Totals & 53 & 97 & 150 \\
\hline
\end{tabular}

In a number of insects the phenotype has been disguised with cellulose paint. All three insects in the cage were marked with paint so that the phenotypes were not treated differently. Not enough results have been obtaincd for any definite conclusions to be formed, but the data suggest that the mating behaviour is not influenced by visual stimuli. It is likely that scent is important as females use it to " assemble" the males, and, in butterflies at least, males are known which employ "scent organs" to induce the female to mate (Eltringham, 1933).

It is not known whether this disassortative mating takes place in the wild but it is probable that it does to some extent. Even if the 
female of any genotype is equally attractive to all the males, the control exercised by the female will have some effect as she often " assembles" a large number of males before she mates. This will result in competition between the males, and those which have a short courtship time will have a better chance of mating. If this tendency to nonrandom mating occurs in the wild, the number of heterozygotes will be increased above the value expected in a random mating system. Moreover, because the males, but not the females, mate more than once, the medionigra males will have a better chance of mating than the wild type males if the gene-frequency be low. This will put them at a slight selective advantage. If this was the only character controlled by the gene, which it is not, stable polymorphism would result. It would be interesting to know if a tendency for unlike genotypes to mate is as common in nature as the reverse situation.

The apparently widespread tendency for genes to have manifold effects is of considerable importance from the evolutionary point of view, because the more characters a gene controls the more likely it is that any change in the environment will alter its selective value. Wright (1932) has suggested that fluctuations in gene frequency are favourable to rapid evolution and has maintained that for this reason "genetic drift" must be particularly important. However, as Fisher and Ford (1947, 1950) have pointed out, directly it is established that selection is also markedly effective in causing gene-frequency fluctuations then "drift" loses its special importance in evolutionary theory.

Acknowledgments.-I am indebted to the Department of Scientific and Industrial Research for a grant during the period of this investigation. Grateful acknowledgment is also made to the Nuffield Foundation for its support.

\section{REFERENCES}

ELTRINGHAM, H. I933. The Senses of Insects. London: Methuen.

FISHER, R. A., AND FORD, E. B. 1947. The spread of a gene in Natural Conditions in a Colony of the moth Panaxia dominula L. Heredity, I, I43-1 74.

FISHER, R. A., AND FORD, E. B. I950. The "Sewall Wright effect". Heredity, 4, I I 7-I I 9 .

Kettlewell, H. B. D. 1942. A survey of the insect Panaxia (Callimorpha) dominula L. Proc. S. Lond. ent. nat. Hist. Soc. (1942-1943), I-49.

SHEPPARD, P. M. I95I. A quantitative study of two populations of the moth Panaxia dominula (L). Heredity, 5, 349-378.

WRIGHT, s. 1932. The roles of mutation, inbreeding, cross-breeding, and selection in evolution. P. Int. Gen. C. (6) $I, 356-366$. 